\title{
Influence of Pressure Application Before Light-Curing on the Bond Strength of Adhesive Systems to Dentin
}

\author{
Christian Ralf GERNHARDT ${ }^{1}$ \\ Katrin BEKES ${ }^{1}$ \\ Petra $\mathrm{HAHN}^{2}$ \\ Hans-Günter SCHALLER ${ }^{1}$ \\ ${ }^{1}$ Department of Operative Dentistry and Periodontology, University School of Dental Medicine, \\ Martin-Luther-University Halle-Wittenberg, Halle, Germany \\ ${ }^{2}$ Department of Operative Dentistry and Periodontology, University School of Dental Medicine, \\ Albert-Ludwigs-University, Freiburg, Germany
}

\begin{abstract}
This study evaluated the influence of defined pressure application before light-curing on the tensile bond strength (TBS) of two adhesive systems to wet and perfused dentin. Bonding sites were analyzed by scanning electron microscopy (SEM) to assess morphological changes. Dentin discs from 120 human third molars were prepared in such a way to allow simulation of intrapulpal pressure. The specimens were randomly assigned to 6 groups $(n=20)$ according to different experimental conditions. The adhesive systems (Scotchbond ${ }^{\mathrm{TM}}$ Multi-Purpose and Syntac ${ }^{\circledR}$ ) were applied either to wet or perfused dentin. In the latter, compression was applied before adhesive light-curing. TBS was recorded using an universal testing machine. Qualitative examination of the bonding sites was performed by SEM after dissolving the dentin with 50\% nitric acid. Pressure application prior to light-curing resulted in a remarkable decrease of TBS for Syntac ${ }^{\circledR}$, while no significant change was observed for Scotchbond ${ }^{\text {TM }}$ MP. SEM analysis showed no considerable lengthening of the resin tags after pressure application. These findings suggest that application of adhesive systems to dentin under pressure before light-curing had no positive effect on TBS.
\end{abstract}

Key Words: bond strength, adhesive systems, dentin, dentin permeability, pressure.

\section{INTRODUCTION}

Since the introduction of dentin bonding systems to modern dentistry over 40 years ago, extensive research has been undertaken to improve bond strength and clinical properties, and several bonding mechanisms have been discussed.

According to proposed concepts, bonding of adhesive systems to human dentin would rely on chemical approach (1) or a micromechanical retention to pretreated dentin (1). For this purpose, pretreatment of the smear layer and dentin by using acids, primers or conditioners is recommended. Smear layer can be removed by the total acid-etching technique, which is known to have a positive effect on bond strength of adhesive systems (2) or the smear-covered dentin surface can be treated with acidic primers or conditioners. Recently introduced self-etching adhesive systems do not require the phosphoric acid etching step (3).

It is accepted that hybrid layer formation by the penetration of hydrophilic monomers into demineralized, intertubular dentin is essential for an adequate bond strength(2). However, it is unknown whether the penetration of hydrophilic monomers, which is based on their chemical properties, can be enhanced by a mechanical component, e.g. application of compressive force before light-curing. Therefore, this study evaluated the influence of defined pressure application before light-curing on the TBS of two adhesive systems to wet and perfused dentin. A qualitative analysis of the bonding sites was also performed by scanning electron microscopy (SEM) to assess morphological changes.

Correspondence: Dr. Christian R. Gernhardt, Martin-Luther-University Halle-Wittenberg, University School of Dental Medicine Department of Operative Dentistry and Periodontology, Grosse Steinstrasse, 19 D- 06108 Halle/Saale, Germany. Tel: +49-345-557-3762. Fax: +49-345-557-3773. e-mail: christian.gernhardt@medizin.uni-halle.de 


\section{MATERIAL AND METHODS}

One hundred and twenty caries-free freshly extracted third molars were selected and stored in saline (Merck, Darmstadt, Germany) at room temperature for a maximum of $24 \mathrm{~h}$. Ninety teeth were used for TBS evaluation and 30 teeth were used for SEM analysis.

For simulation of intrapulpal pressure and dentin perfusion, the specimens were prepared according to a special procedure previously described $(4,5)$. The teeth were decoronated with a water-cooled diamond-coated band saw (Exakt Trennschleifsystem; PSI Grünwald, Laudenbach, Germany). Pulp was removed and occlusal reduction was performed using cylindrical diamond burs (Brasseler, Lemgo, Germany) under constant water cooling. The distance between the pulp chamber and the occlusal plateau was adjusted to 1.3 $\mathrm{mm}( \pm 0.1 \mathrm{~mm})$ and the specimens were apically reduced (parallel to the established flat plane) until specimen thickness reached $3.5 \mathrm{~mm}( \pm 0.2 \mathrm{~mm})$. After preparation, the specimens were mounted on an experimental apparatus (Fig. 1) and simulation of intrapulpal pressure and physiological dentin perfusion using saline was enabled. The pressure was adjusted to $30 \mathrm{~cm} \mathrm{H}_{2} \mathrm{O}$ and maintained over throughout the experiment (Fig. 1). A metal ring was then positioned on the occlusal plane and application of the adhesive systems and composite resin into the ring provided a standardized bonding area.

Two adhesive systems (Syntac ${ }^{\circledR}$; Vivadent, Schaan, Liechtenstein and Scotchbond ${ }^{\mathrm{TM}}$ Multi-Purpose; 3M Dental Products, Loughborough, Great Britain) were used. The materials' principal ingredients are:

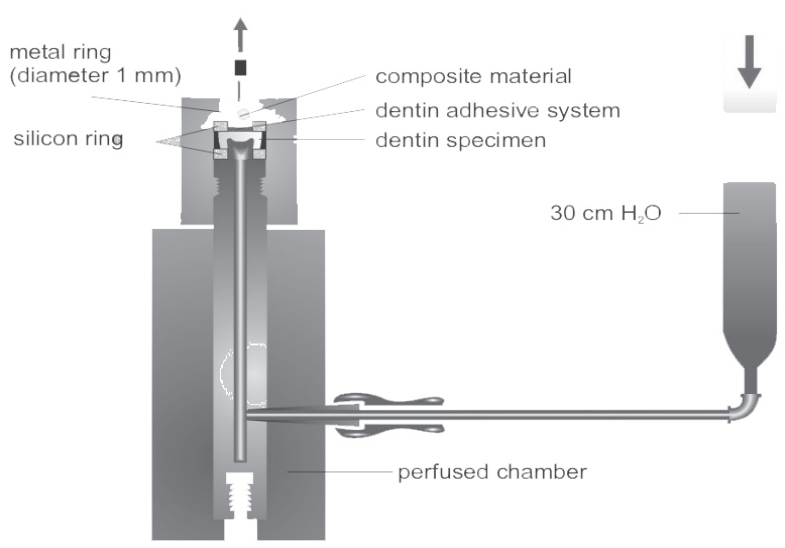

Figure 1. Experimental apparatus designed to TBS testing of composite resin to wet and perfused dentin.
Syntac $^{\circledR}$ - Primer: Tetraethylenglycolmethacrylate, maleic, acid, dimethylketone, water; Adhesive: polyethyleneglycoldimethacrylate, maleic acid, glutaraldehyde and water; Heliobond: Bis-GMA, dimethacrylate, initiators and stabilizers; Scotchbond ${ }^{\mathrm{TM}} \mathrm{MP}$ - Etchant: $36 \% \mathrm{H}_{3} \mathrm{PO}_{4 ;}$ Primer: Polyalkenoic acid, HEMA, water; Adhesive: BisGMA, HEMA.

The specimens were allocated to 6 groups $(\mathrm{n}=20)$, according to 3 experimental conditions: SW0 (Syntac ${ }^{\circledR}$ ) and SCW0 (Scotchbond ${ }^{\mathrm{TM}}$ MP): adhesive system application to wet dentin + light-curing + composite resin application without pressure; SP0 (Syntac $\left.{ }^{\circledR}\right)$ and SCP0 (Scotchbond $\left.{ }^{\mathrm{TM}} \mathrm{MP}\right)$ adhesive system application to perfused dentin + light-curing + composite resin application without pressure; SP1(Syntac $\left.{ }^{\circledR}\right)$ and SCP1 (Scotchbond $\left.{ }^{\mathrm{TM}} \mathrm{MP}\right)$ : adhesive system application to perfused dentin + no light-curing + composite resin application under pressure $(7 \mathrm{~N})+$ light-curing.

The applied pressure of $7 \mathrm{~N}$ was determined in two series of preliminary tests involving 5 dentists and 5 dental students. The pressure applied by the volunteers while placing composite material in a standardized cavity was measured using a universal testing machine (Zwick, Ulm, Germany). The mean pressure was $7 \mathrm{~N}$.

The same light-curing unit (Elipar Visio; Espe, Seefeld, Germany; $400 \mathrm{~mW} / \mathrm{cm}^{2}$ ) was used for adhesive and composite polymerization. The adhesive systems were applied as per manufacturers' instructions. Syntac ${ }^{\circledR}$ : Syntac ${ }^{\circledR}$ Primer was applied and air-thinned after $15 \mathrm{~s}$, Syntac $^{\circledR}$ Adhesive was applied and dried after $10 \mathrm{~s}$, and, finally, Heliobond ${ }^{\circledR}$ (Vivadent, Schaan, Liechtenstein) was applied and blown to a thin layer. Scotchbond ${ }^{\mathrm{TM}}$ $M P: 36 \%$ phosphoric acid gel was applied to dentin, rinsed after $15 \mathrm{~s}$, Scotchbond ${ }^{\mathrm{TM}}$ MP Primer was applied for $5 \mathrm{~s}$ and blown to a thin layer, and, finally, Scotchbond ${ }^{\mathrm{TM}}$ MP Adhesive was applied. Excess was removed with a mild compressed air stream. Tetric ${ }^{\circledR}$ hybrid composite resin (Vivadent, Schaan, Liechtenstein; shade A3) was used in all groups. The metal ring of the test apparatus was filled with the composite in 2-mmthick increments that were light-cured for $60 \mathrm{~s}$.

Fifteen minutes after polymerization, TBS was tested in 15 specimens of each group using a universal testing machine (Zwick, Ulm, Germany) at a crosshead speed of $1 \mathrm{~mm} / \mathrm{min}$. Maximum force until fracture was recorded from a personal computer and presented graphically. TBS was expressed as MPa. TBS means and standard deviations were calculated. Repeated mea- 
sures ANOVA were used to evaluate the results (SAS Release 6.12). Differences among groups were calculated by Tukey's Studentized Range test and by the more sensitively closed test procedure (based on Kruskal Wallis test). Significance level was set at 5\%.

Twenty in after light-curing, the 5 specimens of each group were prepared for qualitative analysis. They were immersed in 50\% nitric acid for a minimum of 48 $\mathrm{h}$ to dissolve dentin hard tissue, then were carefully diluted in distilled water, dried, mounted on aluminium stubs using a conductive silver agent (Silver Print; GC, Tokyo, Japan), sputter-coated with gold in a 15-20 nm layer (SCD 040; Balzers, Wiesbaden, Germany) and analyzed with a scanning electron microscope (DSM 950; Zeiss, Oberkochen, Germany).

\section{RESULTS}

The influence of the adhesive systems and application conditions on TBS were statistically significant $(\mathrm{p} \leq 0.001 ;$ ANOVA). TSB means were significantly higher in the groups with wet dentin specimens compared to ones with perfused dentin specimens $(\mathrm{p}<0.05$, Tukey's Studentized Range test).

The mean TBS of SW0 group (9.03 MPa \pm 1.94 $\mathrm{MPa}$ ) was the highest among all groups with statistically significant difference ( $\mathrm{p}<0.05$, closed test procedure). The mean TBS for the corresponding group on perfused

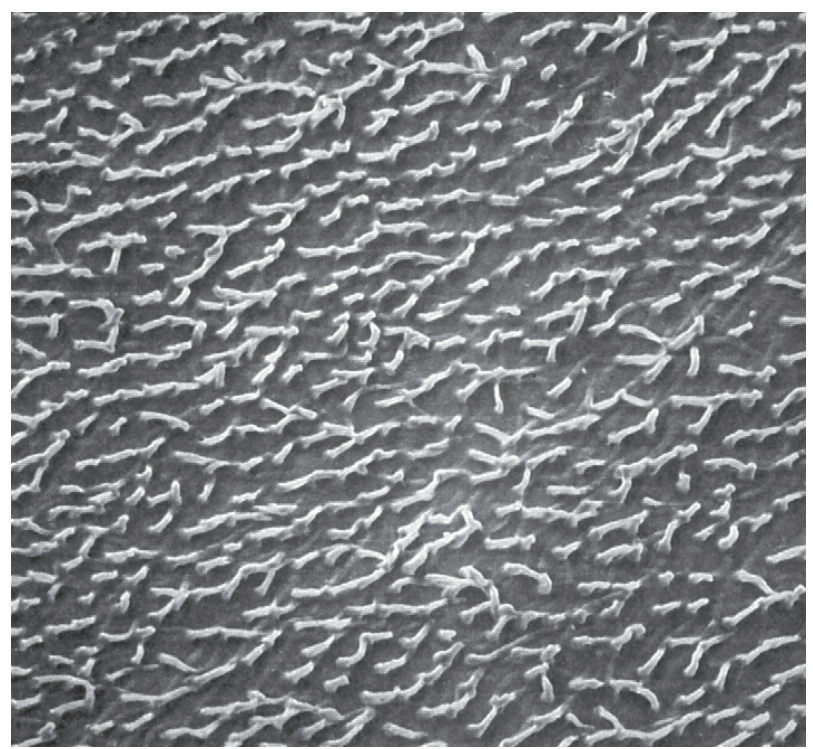

Figure 2. Characteristic tag formation in a wet dentin specimen treated with $\operatorname{Syntac}^{\circledR}(\times 500)$. dentin (SP0 group) was 3.53 MPa ( $\pm 1.07 \mathrm{MPa})$. When pressure was applied before light-curing (SP1 group), the mean TBS dropped to $0.26 \mathrm{MPa}( \pm 0.22 \mathrm{MPa})$, which was significantly lower than that of all tested groups ( $\mathrm{p}<0.05$, closed test procedure).

TBS of SCW0 and SCP0 groups were $6.57 \mathrm{MPa}$ $( \pm 1.79 \mathrm{MPa})$ and $4.26 \mathrm{MPa}( \pm 1.33 \mathrm{MPa})$, respectively, and significant difference $(\mathrm{p}<0.05$, closed test procedure) was found between these groups. When pressure was applied before light-curing (SCP1 group), a mean TBS of $4.97 \mathrm{MPa}( \pm 1.14 \mathrm{MPa})$ was recorded. Closed test procedure showed no statistically significant difference ( $p>0.05)$ between SCP0 and SCP1.

SEM analysis of the specimens treated with Syntac $^{\circledR}$, showed a homogeneous tag formation on wet dentin. Tag mean length was approximately $10 \mu \mathrm{m}$ (Fig. 2). The use of Syntac ${ }^{\circledR}$ on perfused dentin resulted in a more heterogeneous distribution of tags and in a reduction in length to an average of $5 \mu \mathrm{m}$. In SP1 group, the use of compression resulted in nearly no tag formation (Fig. 3). In the groups treated with Scotchbond ${ }^{\mathrm{TM}} \mathrm{MP}$, SEM analysis showed a more extensive and homogeneous tag formation for the wet and perfused dentin specimens (SCW0 and SCP0 groups) compared to the specimens treated with $\mathrm{Syntac}^{\circledR}$ (Fig. 4). After pressure application, (SCP1 group), tag formation did not increase compared to the perfused specimens without pressure. However, occasionally, tags were up to $100 \mu \mathrm{m}$ in length (Fig. 5).

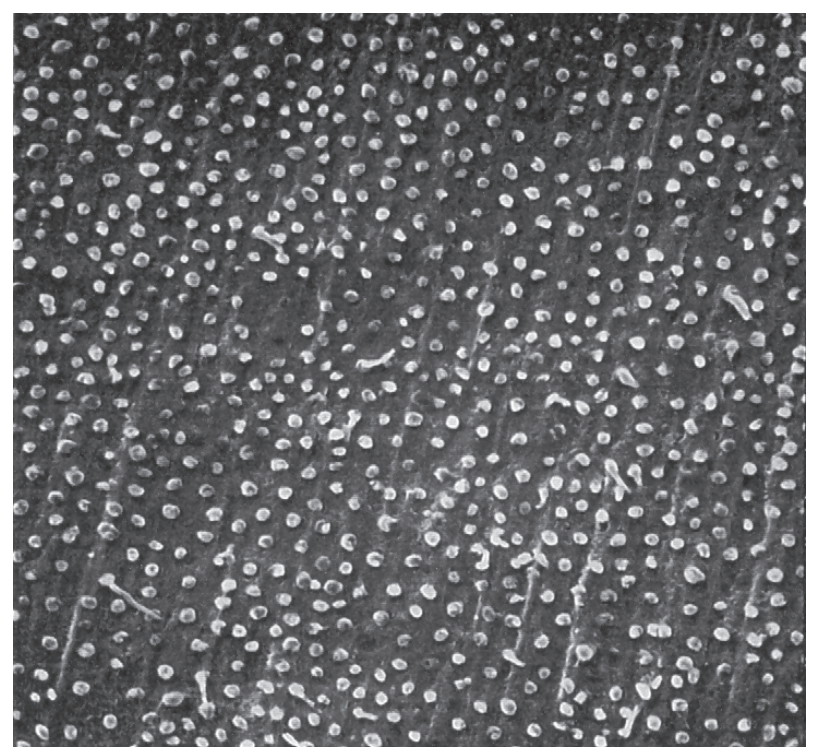

Figure 3. Nearly notag formation in a perfused dentin specimen treated with Syntac $^{\circledR}$ after pressure application before light-curing $(\times 500)$. 


\section{DISCUSSION}

In the present study, saline was used for storage of the freshly extracted teeth. This is a well-known procedure, as it does not influence the chemical and physical properties of human dentin (6). The preparation of the specimens followed a clinical relevant procedure. In contrast to other investigations, preparation was performed using diamond burs under constant water spray, which is known to result in considerably higher bond strength, if compared to other techniques (7-9). It is known that regional differences in dentin anatomy and permeability have a significant influence on dentin bond strength (10). The constant distance between the occlusal plane and the pulp chamber (2.0 $\mathrm{mm} \pm 0.2 \mathrm{~mm}$ ) resulted in fairly well standardized experimental conditions. To eliminate the influence of light intensity and irradiation time, which are known to affect the bond strength (11), the polymerization time in this study was defined to $60 \mathrm{~s}$ using the same light curing unit. In all groups, the same composite material and shade were used in order to avoid composite-related influences on bond strength (12).

Polymerization shrinkage, which occurs during light-curing, has a direct effect on dentinal adhesion and encourages the formation of minifractures. Therefore, it is known that the adhesion force could be measured immediately after application (12). For this reason, in the present study, TBS was measured 15 min after adhesive application application.

In this study, bond strength means were lower than those reported elsewhere (4). In contrast to other studies, the prepared dentin specimens were located in a defined distance close to the pulp chamber. It is known that the use of dentin specimens located farther from the pulp results in higher bond strength (13). The amount of high mineralized peritubular dentin is greater in deep dentin than in the outer regions. Therefore, demineralization and hybrid layer formation is not as efficient as in coronal dentin (14). Moreover, it should be considered that TBS tests tend to provide lower bond strength if compared to shear bond strength measurements. Here, the different stress distribution is known to be the major factor for increased bond strength values.

In the present investigation, the use of Syntac ${ }^{\circledR}$ on wet dentin specimens without perfusion (group SW0) produced the highest TBS means of all groups. The mean TBS for Syntac ${ }^{\circledR}$ on perfused dentin (group SP0: $3.53 \mathrm{MPa}$ ) was significantly lower than that recorded on wet dentin (group SW0: 9.03 MPa). These results are comparable to those of previous investigations

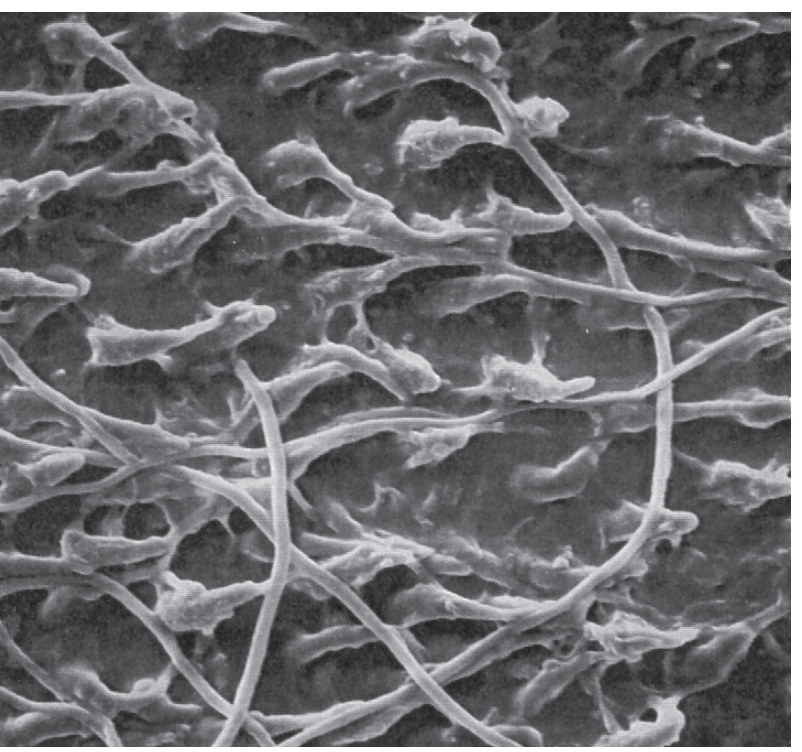

Figure 5. No visible increase in tag formation in a perfused dentin specimen treated with Scotchbond ${ }^{\mathrm{TM}}$ MP and submitted to pressure application $(\times 500)$.
Figure 4. Extensive tag formation with the presence of anastomoses in a perfused dentin specimen treated with Scotchbond ${ }^{\mathrm{TM}}$ MP $(\times 500)$. 
using the same experimental design (4). Regarding Scotchbond ${ }^{\mathrm{TM}} \mathrm{MP}$, a significant decrease of bond strength was detected between wet (SCW0 group: 6.57 $\mathrm{MPa}$ ) and perfused (SCP0 group: 4.26 MPa) dentin . In contrast to the present investigation, Swift and Triolo (15) found higher bond strength for wet dentin than for almost dry dentin using Scotchbond ${ }^{\mathrm{TM}}$ MP. However, they did not tested perfused specimens with simulated, intrapulpal pressure.

The application of Syntac ${ }^{\circledR}$ Primer, which contains maleic acid, and $36 \%$ phosphoric acid etching prior to application of Scotchbond ${ }^{\mathrm{TM}} \mathrm{MP}$, opens and dilates the dentinal tubules, thus increasing dentin permeability (1). Therefore, the simulation of pulpal pressure during in vitro tests is described as indispensable in order to achieve the best comparability in relation to in vivo conditions (2).

For this reason, a constant hydrodynamic pressure of $30 \mathrm{~cm}\left(\mathrm{H}_{2} \mathrm{O}\right)$ was applied in this investigation in 4 groups in order to obtain a perfused tooth substance during the whole experimental period. The simulated intrapulpal pressure $\left(30 \mathrm{~cm} \mathrm{H}_{2} \mathrm{O}\right)$ used in the present study is in a physiological range.

In this study, saline was used as perfusion solution. Isotonic solutions have been considered as suitable to produce a perfusion pressure (16). More recent investigations revealed that diluted human serum has a positive effect on tensile strength $(5,17)$. The given reason is the precipitation of serum proteins in the dentinal tubules, which should lead to a reduced liquid outflow. In the above mentioned studies, a significant increase in tensile strength was described when bovine serum was used compared to saline. When saline was used for perfusion, TBS is almost identical to the values determined in the present study (17).

The application of compression before lightcuring of the composite resin reduced bond strength of Syntac $^{\circledR}$ to an unexpected low level $(0.26 \mathrm{MPa})$. This could be due to some kind of dilution of the composite material applied after the use of the dentin bonding agent and, in the case of Syntac ${ }^{\circledR}$, the additional unfilled bonding resin Heliobond ${ }^{\circledR}$. It seems reasonable that light-curing of the bonding resin will be partially inhibited by the composite material (18). Thus, complete polymerization of the unfilled dentin bonding agent could not necessarily be expected. Another reason for this outcome could be the destruction of the glutaraldehyde fixed collagen mash by compression.
Probably Syntac ${ }^{\circledR}$ can only establish bonding to dentin if light-cured before application of the composite resin. Other investigators found similar results when comparing bond strength before and after light curing of the dentin adhesive (19).

The SEM analysis could not completely support these findings. The formation of tags decreased in the groups with perfused dentin combined with compression. Syntac ${ }^{\circledR}$ applied to wet dentin showed the highest bond strength. However, compared to Scotchbond ${ }^{\mathrm{TM}} \mathrm{MP}$, tag formation was visibly lower.

It is known that tag formation is only one part of the adhesion mechanism. Obviously, in the case of Syntac $^{\circledR}$, a greater role must be ascribed to the known micromechanical retention than to the formation of tags and chemical bond.

In the group treated with Scotchbond ${ }^{\mathrm{TM}} \mathrm{MP}$, compression before polymerization (SCP1 group) had no significant influence on TBS compared to the perfused group without compression (SCP0 group). Compared to wet dentin (SCW0 group), bond strength was lower, but not significantly reduced. A possible explanation might be the absence of an unfilled bonding resin like Heliobond ${ }^{\circledR}$. Furthermore, hydrophilic monomer penetration might be enhanced in the case Scotchbond ${ }^{\mathrm{TM}}$ MP (20). Regarding SEM analysis, it was observed an increased occurrence of anastomoses between the dentinal tubules in all groups treated with Scotchbond ${ }^{\mathrm{TM}}$ MP. No significant morphological differences could be observed among the three groups treated with Scotchbond ${ }^{\mathrm{TM}}$ MP. This might be due to the improved bonding properties of this material. Several investigators described a significant role in adhesion to the outflow from lateral tubules and to the formation of resin caps on the tags (20). It seems reasonable that for Scotchbond ${ }^{\mathrm{TM}} \mathrm{MP}$, adhesive penetration and tag formation is improved and plays a greater role in the adhesion mechanism compared to Syntac ${ }^{\circledR}$. Furthermore, the results of the present investigation fully agree with previous reports, stressing that pre-curing of the adhesive system causes a significant increase in the dentin bond strength, if compared to curing together with composite placement (19).

The findings of the present study are obviously of clinical significance, as they demonstrate the need to establish a bond between adhesive resin and dentin before composite placement to achieve reliable results. The estimated increase of bond strength due to com- 
pression before light-curing could not be confirmed in the present study.

In the present investigation, the effect of pressure application on the adhesive systems during polymerization seemed to material-dependent. The results showed that compression of composite filling after Syntac $^{\circledR}$ application was deleterious to the adhesive mechanism and resulted in an unacceptable decrease of TBS. The decrease of bond strength of Scotchbond ${ }^{\mathrm{TM}}$ MP to dentin, though noticeable, was not significant. Keeping this results in mind, it is recommendable to follow the manufacturers' instructions and pre-cure dentin bonding systems before placement of composite. It remains to be clarified how other systems would react to compression before light-curing.

\section{RESUMO}

Este estudo avaliou a influência da aplicação de uma pressão definida antes da polimerização sobre a resistência à tração de dois sistemas adesivos à dentina molhada e perfundida. Os sítios de adesão foram analisados em microscopia eletrônica de varredura (MEV) a fim de determinar a ocorrência de alterações morfológicas. Discos de dentina de 120 terceiros molares humanos foram preparados de tal forma a simular a pressão intrapulpar. Os espécimes foram alocados aleatoriamente em 6 grupos $(n=20)$, de acordo com as diferentes condições experimentais propostas. Os sistemas adesivos $\left(\right.$ Syntac $^{\circledR}$ e Scotchbond ${ }^{\mathrm{TM}}$ Multi-Purpose) foram aplicados sobre a dentina molhada ou perfundida. Nesta última, compressão $(7 \mathrm{~N})$ foi aplicada antes da polimerização do sistema adesivo. A resistência à tração foi registrada em máquina universal de ensaios. A análise qualitativa dos sítios de adesão foi realizada em MEV após dissolução da dentina em $50 \%$ de ácido nítrico. A aplicação da pressão antes da polimerização do sistema adesivo resultou em diminuição significativa da resistência à tração do $\operatorname{Syntac}^{\circledR}$, ao passo que para o Scotchbond ${ }^{\mathrm{TM}}$ MP nenhuma alteração significativa foi observada. A análise em MEV não mostrou aumento considerável do tamanho dos tags de resina após a aplicação da pressão. Esses achados sugerem que a aplicação de sistemas adesivos à dentina sob pressão previamente à polimerização não teve efeito positivo sobre a resistência à tração.

\section{REFERENCES}

1. Van Meerbeek B, De Munck J, Yoshida Y, Inoue S, Vargas M, Vijay $\mathrm{P}$ et al. Buonocore memorial lecture. Adhesion to enamel and dentin: current status and future challenges. Oper Dent 2003;28:215-235.

2. Breschi L, Mazzoni A, Ruggeri A, Cadenaro M, Di Lenarda R, De Stefano-Dorigo E. Dental adhesion review: aging and stability of the bonded interface. Dent Mater 2008;24:90-101.

3. Chan KM, Tay FR, King NM, Imazato S, Pashley DH. Bonding of mild self-etching primers/adhesives to dentin with thick smear layers. Am J Dent 2003;16:340-346.

4. Gernhardt CR, Kielbassa AM, Hahn P, Schaller HG. Tensile bond strengths of four different adhesive systems on irradiated and non-irradiated human dentin in vitro. J Oral Rehabil 2001;28:814-820.

5. Gernhardt CR, Bekes K, Fechner K, Schaller HG. The influence of human plasma used for in vitro dentin perfusion on microtensile bond strength of 5 self-conditioning adhesive systems. Quintessence Int 2006;37:429-435.

6. Lee JJ, Nettey-Marbell A, Cook A, Jr., Pimenta LA, Leonard R, Ritter AV. Using extracted teeth for research: the effect of storage medium and sterilization on dentin bond strengths. J Am Dent Assoc 2007;138:1599-1603.

7. Sadek FT, Cury AH, Monticelli F, Ferrari M, Cardoso PE. The influence of the cutting speed on bond strength and integrity of microtensile specimens. Dent Mater 2005;21:1144-1149.

8. Gupta R, Tewari S. Effect of rotary instrumentation on composite bond strength with simulated pulpal pressure. Oper Dent 2006;31:188-196.

9. Reis A, Rocha de Oliveira Carrilho M, Schroeder M, Tancredo $\mathrm{LL}$, Loguercio AD. The influence of storage time and cutting speed on microtensile bond strength. J Adhes Dent 2004;6:7-11.

10. Inoue S, Pereira PN, Kawamoto C, Nakajima M, Koshiro K, Tagami $\mathrm{J}$ et al.. Effect of depth and tubule direction on ultimate tensile strength of human coronal dentin. Dent Mater J 2003;22:39-47.

11. Yamamoto A, Tsubota K, Takamizawa T, Kurokawa H, Rikuta A, Ando S et al.. Influence of light intensity on dentin bond strength of self-etch systems. J Oral Sci 2006;48:21-26.

12. Ilie N, Kunzelmann KH, Hickel R. Evaluation of micro-tensile bond strengths of composite materials in comparison to their polymerization shrinkage. Dent Mater 2006;22:593-601.

13. Kaaden C, Powers JM, Friedl KH, Schmalz G. Bond strength of self-etching adhesives to dental hard tissues. Clin Oral Investig 2002;6:155-160.

14. Yesilyurt C, Bulucu B. Bond strength of total-etch and selfetch adhesive systems on peripheral and central dentinal tissue: a microtensile bond strength test. J Contemp Dent Pract 2006;7:26-36.

15. Swift EJ, Jr., Triolo PT, Jr. Bond strengths of Scotchbond Multi-Purpose to moist dentin and enamel. Am J Dent 1992;5:318-320.

16. Pioch T, Staehle HJ, Schneider H, Duschner H, Dorfer CE. Effect of intrapulpal pressure simulation in vitro on shear bond strengths and hybrid layer formation. Am J Dent 2001;14:319-323.

17. Gernhardt CR, Schaller HG, Kielbassa AM. The influence of human plasma used for dentin perfusion on tensile bond strength of different light-curing materials. Am J Dent 2005;18:318-322.

18. Hickel R, Heid M, Kunzelmann KH, Petschelt A. Curing depth of light curing composites under ceramic material. Dtsch Zahnärztl Z 1992;47:182-185.

19. Coelho Santos MJ, Navarro MF, Tam L, McComb D. The effect of dentin adhesive and cure mode on film thickness and microtensile bond strength to dentin in indirect restorations. Oper Dent 2005;30:50-57.

20. Chappell RP, Eick JD. Shear bond strength and scanning electron microscopic observation of six current dentinal adhesives. Quintessence Int 1994;25:359-368.

Accepted October 10, 2006 